UDC 615.25.252.349.7:615.451.16:582.894.6

DOI: 10.15587/2519-8025.2021.234727

\title{
PROSPECTS FOR APPLICATION OF PHYTOPREPARATIONS IN THE COMPLEX TREATMENT OF TYPE 2 DIABETES MELLITUS
}

\author{
Viktoria Rybak, Lyudmila Maloshtan, Victoria Korol
}

Diabetes mellitus (DM) occupies an important place in the structure of mortality, as well as among the causes of disability and deterioration in the quality of life of the population. In this regard, the study of phytopreparations is promising for practical medicine in order to identify new medicinal plants that actively affect metabolic processes to prevent complications of DM, and create new phytopreparations. That drugs could enhance the effect of sulfonamides and potentiate the effect of insulin, thereby reducing the dose of the latter, and it is important for long-term chronic diseases, such as DM.

The aim. To study the prospects for the use of phytopreparations in the complex treatment of type 2 diabetes mellitus. Materials and methods. The analytical, logical, generalization methods were used in the work. The analytical method of the study involved deepening the search for phytopreparations and the prospects for their use in the complex treatment of type 2 diabetes mellitus and generalization of the data obtained. The logical method of exploratory research of promising phytopreparations was applied in a certain logical sequence, as a result of which the specificity, stage-bystage and generalization of the relevance of the use of phytopreparations in the complex treatment of type 2 diabetes mellitus was provided for scientific research. The generalizing research method was to determine and prove the characteristics of phytopreparations (analysis and synthesis) and their advantages over synthetic drugs.

Results and discussion. The main directions of herbal medicine for DM are associated with reproduction of the effects of insulin, normalization of glucose uptake, stimulation of regeneration of $\beta$-cells of the Langerhans islets, elimination of excess glucose from the body - phytopreparations with diuretic properties; elimination of hypoxia - phytopreparations-antihypoxants. In DM, herbal medicine will reduce the frequency of side effects in classical antidiabetic therapy. For any type of diabetes, herbal medicine is prescribed to patients as an improvement in the microcirculation of tissues, normalization of the functions of the cardiovascular and nervous systems, kidneys and eyes.

Conclusions. Despite a wide range of drugs used to correct the hemodynamic and metabolic manifestations of the insulin resistance syndrome, they do not fully meet the needs of practical medicine due to the presence of pronounced side effects. In addition, the pharmaceutical market of herbal medicines is very limited and represented mainly by species of medicinal plants, which have certain inconveniences in their use. All this indicates the relevance of the search, creation and introduction of effective and, at the same time, low-toxic drugs based on the medicinal plant raw material into medical practice for the pharmacotherapy of type 2 diabetes and its complications

Keywords: herbal medicine, medicinal plants, type 2 diabetes mellitus

How to cite:

Rybak, V., Maloshtan, L., Korol, V. (2021). Prospects for application of phytopreparations in the complex treatment of type 2 diabetes mellitus. ScienceRise: Biological Science, 2 (27), 18-22. doi: http://doi.org/10.15587/2519-8025.2021.234727

\section{Introduction}

Diabetes mellitus (DM) occupies one of the leading places in the structure of mortality, as well as among the causes of disability and deteriorating quality of life [1]. Today there are more than 415 million DM patients in the world. In Ukraine, the number of registered patients with DM reached 1,300,000 people, more than 193 thousand of whom are insulin-dependent [2]. There are high frequency of complications from DM, which is due to disorders of tissue metabolism with damage to the microcapillary bed of organs, which leads to the formation of multiorgan pathology [3].

For the treatment of type $2 \mathrm{DM}$ are widely used synthetic drugs - sulfonylureas and biguanides [4], as well as drugs of plant origin - Phaseolus vulgaris fruit valves, teas, “Arphasetin", Sucontrol, Diabetonitis, Agadiabet, Amelin, Hypoglycine, etc. [5].

\subsection{Phytopreparations in the DM treatment}

The study of phytopreparations is promising for practical medicine in order to identify new medicinal plants that actively influence metabolic processes, to prevent complications of DM and to create new herbal medicines that can enhance the effect of sulfonamides and potentiate the effect of insulin, thereby reducing the dose of the latter, which is important in such a long-term chronic disease as DM.

The use of medicinal plants in the treatment of DM is based on the fact that a significant number of them (over 400) have a hypoglycemic effect. In addition, these plants have a number of other positive effects, which, of 
course, enhances their effect in the presence of complicated diabetes, as the latter provokes a wide range of lesions from various organs and systems. The greatest therapeutic effect from the use of medicinal plants is observed in the case of DM type $2[6,7]$.

The main active ingredients of medicinal plants are alkaloids, saponins and other biologically active substances. Glucans and peptidoglucans with hypoglycemic action have been found in some plants [8]. The mechanisms of hypoglycemic action of medicinal plants are intensively studied, and researchers have now proposed several hypotheses [8].

All medicinal plants that have a hypoglycemic effect can be used alone in the form of infusions, decoctions or various mixtures, so-called collections of medicinal plants or teas. Synergism and even potentiation of the action of biologically active substances that are part of medicinal plants can often be observed during treatment with mixtures [9].

\section{Literature review}

A promising way to solve the problem of drug safety is the use of drugs based on biologically active substances of various plants $[10,11]$. The use of herbal raw materials to create drugs is explained by many reasons. First, the components that are part of the drugs, due to the wide range of pharmacological action and low toxicity have a complex effect on the body and rarely cause serious side effects. This allows for longterm treatment of chronic diseases. The active substances that are part of plants often show a high affinity for the enzyme systems of the body and therefore relatively easily enter the metabolic processes. An important feature of many herbal medicines is the availability of raw materials, substantiating an economical advantage to product a drug [8].

Herbal preparations are widely used in the correction of pre-diabetes and in the complex therapy of DM. Prior to the discovery of insulin and the creation of the first synthetic hypoglycemic agents, extracts of many medicinal plants were used as the main ways of lowering blood glucose [6].

Medicinal teas are the oldest dosage form for the introduction of active substances into the patient's body. They are easy to use, have pleasant taste and well preserved for a long time.

It is known that any disease affects not one specific organ, but the whole body, so herbal medicine is effective if it is carried out with a mixture of plants that affect the body and at the same time have a beneficial effect on a particular disease $[6,12,13]$.

The use of medicinal plants in such cases is associated with the rational selection of plants and their mixtures. Professionally prepared and timely applied composition, strict adherence to the prescribed regimen, combined herbal medicine with other treatments allow for maximum improvement or complete cure of the disease [14].

\subsection{The main directions of DM phytotherapy}

Reproduction of insulin effects, normalization of glucose absorption, stimulation of $\beta$-cell regeneration of islets of Langerhans, excretion of excess glucose are pro- vided with phytopreparations with diuretic properties, and elimination of hypoxia - phytopreparationsantihypoxants [6, 8, 9, 12, 15-17].

Phytotherapy in the presence of DM is carried out constantly, throughout the life of the patient without interruption, under the supervision of a physician; teas are alternated. Prolonged herbal medicine improves the general well-being of patients. Hyperglycemia is reduced, which allows you to reduce the dose of antidiabetic drugs or even cancel their use. Phytotherapy in many cases protects the body from damage to the cardiovascular system, kidneys and liver, diabetic neuro- and retinopathy or delays their occurrence [14, 17-19].

The aim of the study was to determine the prospects for the use of phytopreparations in the complex treatment of type $2 \mathrm{DM}$.

\section{Materials and methods}

Analytical, logical, generalizing methods are used in the work. The analytical method of the research has involved immersion in the search for phytopreparations and prospects for their use in the complex treatment of type 2 diabetes and generalization of the obtained data. The logical method of exploratory research of promising phytopreparations was used in a certain logical sequence, as a result of which specificity, phasing and validity of scientific research on the relevance of application in the complex treatment of type 2 diabetes mellitus were provided for scientific research. The generalizing method of research consisted in definition and provability of characteristics of phytopreparations (analysis and synthesis) and their advantages over synthetic medicines.

\section{Research results \\ 4.1. Patented antidiabetic teas: composition, ef- fectiveness, application}

Recently, new medicinal teas that have a hypoglycemic effect have appeared in Ukraine. They include medicinal plants that do not grow in Ukraine [20]. These are primarily "Diabetin" and Ceylon herbal tea No. 786 (Table 1).

"Arphasetin" normalizes metabolic disorders caused by DM, lowers blood glucose, enhances the glycogen-synthesizing function of the liver, has antiinflammatory, membrane-stabilizing, tonic effects, accelerates the regeneration of the endocrine parenchyma of the pancreas.

Prolonged use of "Arphasetin" may cause heartburn, allergic reactions, high blood pressure. Another disadvantage is the inconvenience when using the collection by patients, which is associated with the preparation of the decoction, with the inability to use it in the afternoon to avoid sleep disorders [6].

Ceylon anti-diabetic herbal tea № 786 and "Diabetin" tea have a complex hypoglycemic effect. It may potentiate the effect of oral antidiabetic drugs when used concomitantly.

Patients generally tolerate phytopreparations well, because the latter have a mild taste, easy to use, with regular use show a slight tonic effect, have a positive effect on the digestive tract $[15,16]$. 
Table 1

The content of medicinal plants in patented antidiabetic fees

\begin{tabular}{|c|c|c|}
\hline “Arphasetin" & JAF “Diabetin” & Ceylon herbal tea No. 786 \\
\hline $\begin{array}{c}\text { Vaccinium myrtillus } \mathrm{L} . \\
\text { (shoots) } 4 \mathrm{p}\end{array}$ & $\begin{array}{c}\text { Syzygum cumini } \\
\text { (seeds and roots) } 3 \mathrm{p} .\end{array}$ & $\begin{array}{c}\text { Aerva lanata Juss } \\
\text { (leaves, seeds) } 1.1 \mathrm{p} .\end{array}$ \\
\hline $\begin{array}{c}\text { Phaseolus vulgaris } \mathrm{L} . \\
\text { (valves) } 4 \mathrm{p} .\end{array}$ & $\begin{array}{c}\text { Cassia auriculata Linn } \\
\text { (bark, seeds, flowers, roots) } 1.5 \mathrm{p} .\end{array}$ & $\begin{array}{c}\text { Cassia auriculata Linn } \\
\text { (leaves, seeds, fruits) } 1.5 \mathrm{p} .\end{array}$ \\
\hline $\begin{array}{c}\text { Rosa canina } \mathrm{L} . \\
\text { (fruits) } 3 \mathrm{p} .\end{array}$ & $\begin{array}{c}\text { Ficus racemosa } \mathrm{L} . \\
\text { (bark, seeds) } 1.5 \mathrm{p} .\end{array}$ \\
\hline $\begin{array}{c}\text { Aralia manshurica } \mathrm{L} . \\
\text { (roots) } 3 \mathrm{p}\end{array}$ & - & $\begin{array}{c}\text { Astercanatha } \text { seeds) } \\
\text { (herb) } 1.1 \mathrm{p} \text {. }\end{array}$ \\
\hline $\begin{array}{c}\text { Hypericum } \text { perforatum } \mathrm{L} . \\
\text { (herb) } 2 \mathrm{p} .\end{array}$ & $\begin{array}{c}\text { Tinospora cordifolia } \\
\text { (all parts of plant) } 0.9 \mathrm{p} .\end{array}$ \\
\hline $\begin{array}{c}\text { Chamomilla recutita } \mathrm{L} . \\
\text { (flowers) } 2 \mathrm{p} .\end{array}$ & - & - \\
\hline $\begin{array}{c}\text { Equisetum arvense } \mathrm{L} . \\
\text { (herb) } 2 \mathrm{p} .\end{array}$ & - & - \\
\hline
\end{tabular}

In some countries, herbal remedies are used to treat DM - Sucontrol, Diabetonitis, Agadiabetes, Amelin, Hypoglycine and others.

Herbal medicine can reduce the frequency of side effects from classical antidiabetic therapy. For any type of DM, patients are recommended herbal medicine to improve tissue microcirculation, normalize the functions of the cardiovascular and nervous systems, kidneys and eyes [21].

Patients with DM should adjust the composition of phytocompositions every two months, and phytopreparations that have sedative, adaptogenic, hepatoand gastroprotective properties - every two weeks due to changes in the receptor apparatus of organs and tissues [22-24].

When using medicinal plants with diuretic and sorption properties, plants containing magnesium (currants, blackberries, raspberries, knotweed, birch, elderberry, lagochilus, celandine) and potassium (persimmon, apricot, banana, peach, anise, arnica, elderberry, astragalus, knotweed, nettle) [20, 16, 25, 26].

Some medicinal plants (Eleutherococcus, ginseng, temptation, aralia, lemongrass, rhodiola, levzeya) together with hypoglycemic action exhibit immunocorrective properties, which is necessary in the complex therapy of patients with DM. These plants increase the level of GMF in the liver and muscles, providing insulin-like action $[15,20]$.

Despite the availability and relative cheapness of domestic phytomedicines (especially against foreign ones), the Ukrainian market of hypoglycemic drugs of plant origin is quite limited.

\section{Discussion of research results}

5.1. Pharmacological properties of Phaseolus vulgaris as a basis for the development of potential agents for the treatment of type 2 DM and its complications

A large arsenal of medicinal plants is used to treat patients with DM. Researchers' interest in Phaseolus vulgaris of the legume family (Fabaceae) is due to the hypoglycemic effect that was discovered in the early twentieth century. Noorden noted the possibility of treating DM with Phaseolus vulgaris, but for the first time experimen- tally substantiated and used beans for the treatment of patients with DM by E. Kaufman.

The valves of Phaseolus vulgaris fruits, known in medicine as Phaseoli pericarpium, have a hypoglycemic effect, which is why they are called "plant insulin" and it is believed that this part of the plant of all varieties of Phaseolus vulgaris is suitable for use. It is known that one glass of infusion of Phaseolus vulgaris valves corresponds to three units of insulin [5, 8, 27-30].

The healing properties of Phaseolus vulgaris are used in gastritis with low acidity, chronic pancreatitis, kidney stones, atherosclerosis and arrhythmias, ulcers and eczema. In folk medicine, a decoction of Phaseolus vulgaris pods is successfully used to treat hypertension, heart failure, edema, chronic rheumatism, gout and DM. Beans have diuretic, antimicrobial and hypoglycemic properties. The hypoglycemic effect of Phaseolus vulgaris is explained by the presence of arginine - an insulin-like substance. Phaseolus vulgaris contains betaine, arginine, tryptophan, tyrosine, leucine, asparagine, choline, hemicellulose (up to $50 \%$ ), inositol $(0.75 \%)$, sugars, organic and fatty acids, saponins, flavonoids and coumarins [22, 27, 28, 31-35].

Phaseolus vulgaris valves of fruits and tea "Arphasetin" (CJSC "Liktravy", Ukraine) are registered as medicines. Drugs from Phaseolus vulgaris have hypoglycemic, anti-inflammatory, diuretic, reparative and desensitizing effects, promote the secretion of gastric juice. In addition, the aqueous extract of Phaseolus vulgaris has antibiotic properties [8].

Based on materials presented by practitioners and scientists engaged in phytotherapy, considered medicinal plants and compositions of fees that exhibit antidiabetic properties with varying degrees of activity, grow naturally and are an inexhaustible source of natural remedies [6, 15, 24, 36].

Study limitations. A limitation on the use of phytopreparations is the individual intolerance of the components of the active compounds that are part of the phytocomposition.

Prospects for further research. Development and implementation in medical practice of antihyperglycemic phytopreparation for the treatment of type $2 \mathrm{DM}$ based on Phaseolus vulgaris valves of fruits is based on its effectiveness in lowering blood sugar, on extraglycemic effects 
that can stop the development of chronic complications, on safety application and affordability of the drug.

\section{Conclusions}

1. Analysis of the nomenclature of synthetic and herbal drugs for the treatment of type 2 DM showed that despite the wide range of drugs used to correct hemodynamic and metabolic manifestations of insulin resistance syndrome, they do not fully meet the needs of practical medicine due to the presence of significant side effects. The pharmaceutical market of phytopreparations is very limited and is represented mainly by collections of medicinal plants, which during application cause certain inconveniences (brew, infuse, use in warm or chilled form).

2 . In the treatment of type 2 diabetes mellitus, preference is given to hypoglycemic drugs from bean leaves, which are very popular not only due to the pronounced hypoglycemic, but also other types of pharmacological activity (anti-inflammatory, diuretic, antimicrobial, reparative, desensitizing).
3. All this indicates the urgency of creating and implementing in medical practice effective and at the same time low-toxic drugs based on domestic medicinal herbal raw materials for pharmacotherapy of type $2 \mathrm{DM}$ and its complications.

\section{Conflict of interests}

The authors declare that they have no conflicts of interest.

\section{Financing}

The study was performed without financial support.

\section{Acknowledgments}

For further pharmacological research, as a phytopreparation for the treatment of type 2 diabetes mellitus, a thick extract of Phaseolus vulgaris was developed under the guidance of doctor of pharmacy, prof. of department of pharmacognosy NUPh Kovalev V. M., for which the author is grateful.

References
1. Shcherbak, Y. B. (2013). Vsemyrnii den dyabeta - 2013 v Ukrayne : kurs na dyabetolohycheskoe prosviashchenye y profilaktyku. Ukrainskyi medychnyi chasopys, 6 (98), 20-21.

2. Kikhtiak, O. P. (2013). Mekhanizmy rozvytku insulinorezystentnosti ta yii misheni. Ukrainskyi medychnyi chasopys, 5 (97), 99-101.

3. Kravchun, N. A., Chernyavskaya, I. V. (2012). Kompleksnaya terapiya mikrososudistykh oslozhneniy u patsientov s sakharnym diabetom 2-go tipa s primeneniem antitromboticheskikh preparatov. Mezhdunarodniy endokrinologicheskiy zhurnal, 5 (45), 31-35.

4. Bharti, S. K., Krishnan, S., Kumar, A., Kumar, A. (2018). Antidiabetic phytoconstituents and their mode of action on metabolic pathways. Therapeutic Advances in Endocrinology and Metabolism, 9 (3), 81-100. doi: http://doi.org/10.1177/2042018818755019

5. Kovalov, V. M., Kovalov, S. V., Demeshko, O. V., Dmytryievskyi, D. I., Kutsanian, A. S., Maloshtan, L. M., Rybak, V. A. (2015). Pat. No. 101843 UA. Sposib oderzhannia biolohichno aktyvnykh rechovyn z hipohlikemichnoiu diieiu. MPK A61K 36/48, A61R 3/10 (2006.01). No. a 201413120; declareted: 08.12.2014; published: 12.10.2015, Bul. No. $19,4$.

6. Konechna, R. T., Novikov, V. P. (2008). Fitozasoby v likuvanni tsukrovoho diabetu. Visnyk Natsionalnoho universytetu «Lvivska politekhnika», 622, 64-70.

7. Niu, C.-S., Chen, L.-J., Niu, H.-S. (2014). Antihyperglycemic action of rhodiola-aqeous extract in type1-like diabetic rats. BMC Complementary and Alternative Medicine, 14 (1). doi: http://doi.org/10.1186/1472-6882-14-20

8. Chernykh, V. P. et. al. (2010). Suchasni aspekty peroralnoi farmakoterapii tsukrovoho diabetu 2 typu. Dosiahnennia NFaU. Kharkiv: BURUN i K, 208.

9. Ota, A., Ulrih, N. P. (2017). An Overview of Herbal Products and Secondary Metabolites Used for Management of Type Two Diabetes. Frontiers in Pharmacology, 8. doi: http://doi.org/10.3389/fphar.2017.00436

10. Lupak, M. I., Khokhla, M. R., Hachkova, G. Ya., Kanyuka, O. P., Klymyshyn, N. I., Chajka, Ya. P. et. al. (2015). The alkaloidfree fraction from Galega officinalis extract prevents. The Ukrainian Biochemical Journal, 8 (4), 78-86. doi: http://doi.org/10.15407/ ubj87.04.078

11. Dedov, I. I., Shestakova, M. V. (Eds.) (2015). Algoritmy spetsializirovannoy meditsinskoy pomoschi bolnym s diabetom. Moscow, 7, 1-112.

12. Prykhodko, T. (2014). Novi alhorytmy upravlinnia tsukrovym diabetom 2 typu. Vashe zdorovia, 30-31, 22-23.

13. Kryvoruchko, O. V., Kovalov, V. M., Kryvoruchko, V. A. (2009). Analiz lipofilnoho ekstraktu lystia kyzylu. Zhurnal orhanichnoi ta farmatsevtychnoi khimii, 7 (1 (25)), 74-76.

14. Romanova, I. P. et. al. (2014). Do pytannia shchodo dosiahnennia kompensatsii tsukrovoho diabetu 2-ho typu. Problemy endokrynnoi patolohii, 2, 22-28.

15. Blonde, L., Montanya, E. (2012). Comparison of liraglutide versus other incretin-related anti-hyperglycaemic agents. Diabetes, Obesity and Metabolism, 14, 20-32. doi: http://doi.org/10.1111/j.1463-1326.2012.01575.x

16. Kalmykov, S., Kalmykova, J. (2016). The characteristics of the medicinal plants used in the herbal medicine of type 2 diabetes. Slobozans'kij Naukovo-Sportivnij Visnik, 3 (53), 53-58. doi: http://doi.org/10.15391/snsv.2016-3.010

17. Spiridonenko, V. V. (2014). Fitoterapiya khronicheskogo prostatita na fone metabolicheskogo sindroma i sakharnogo diabeta. Urologiya, 1, 36-41.

18. Korpachev, V. V., Huryna, N. M., Korpacheva-Zynich, O. V. (2013). Vytamynno-myneralnii kompleks «Vytamyni dlia bolnikh dyabetom» v terapyy sakharnoho dyabeta y profylatyke eho oslonenyi. Ukrainskyi medychnyi chasopys, 2 (94), $119-123$.

19. Martynyuk, L., Martynyuk, L., Ruzhitskaya, O., Martynyuk, E. (2014). Lechebniy potentsial fitoterapii pri diabeticheskoy nefropatii u patsientov s sakharnym diabetom 2 tipa: rezultaty sravnitelnogo kogortnogo issledovaniya. Medical nature, 3, 30-37.

20. Alekseev, I. S. (2013). Polniy atlas lekarstvennykh rasteniy. Donetsk: OOO «Gloriya Treyd», 400.

21. Guo, J., Wang, J., Song, S., Liu, Q., Huang, Y., Xu, Y. et. al. (2016). Sphallerocarpus gracilis polysaccharide protects pancreatic $\beta$-cells via regulation of the bax/bcl-2, caspase-3, pdx-1 and insulin signalling pathways. International Journal of Biological Macromolecules, 93, 829-836. doi: http://doi.org/10.1016/j.ijbiomac.2016.08.083

22. Pankiv, V. I. (2014). Tsukrovyi diabet 2 typu: upravliaty efektyvno, ne dopuskaiuchy pomylok. Zdorovia Ukrainy. Temat. nomer «Diabetolohiia», 1, 29-30. 
23. Samad, A., Shams, M., Ullah, Z., Wais, M., Nazish, I., Sultana, Y., Aqil, M. (2009). Status of Herbal Medicines in the Treatment of Diabetes: A Review. Current Diabetes Reviews, 5 (2), 102-111. doi: http://doi.org/10.2174/157339909788166837

24. Chekman, I. S., Bondur, V. V., Klymenko, O. V. (2016). Kombinovana farmakoterapiia tsukrovoho diabetu 2-ho typu. Ratsionalna farmakoterapiia, 2 (39), 25-31.

25. Pylypenko, V. M. et. al. (2010). Ratsionalna farmakoterapiia tsukrovoho diabetu 2-ho typu z vykorystanniam endohennykh rezerviv pidshlunkovoi zalozy Problemy. endokrynnoi patolohii, 1, 27-32.

26. IDF Diabetes Atlas (2015). Brussels: International Diabetes Federation, 144. Available at: www.idf.org/diabetesatlas

27. Kovalev, C. V., Kutsanian, A. S., Dmytryevskyi, D. Y., Sitnyk, A. H., Borodyna, N. V., Kovalev, V. N. (2008). K standartyzatsyy substantsyy y lekarstvennoi formi hlyfazyna. Zhurnal orhanichnoi ta farmatsevtychnoi khimii, 6 (2 (22)), 80-82.

28. Kutsanian, A. S., Dmytriievskyi, D. I., Sytnyk, O. H. (2008). Rozrobka skladu ta doslidzhennia supozytoriiv z roslynnym kompleksom «Hlifazyn» dlia likuvannia diabetu. Farmatsevtychnyi chasopys, 3, 6-9.

29. Sovtus, I. M. (2015). Possibilities of diabetes mellitus phytotherapy with medicinalplants of volyn region. Medsestrynstvo, 2, 40-43. (49), 5-8

30. Bletskan, M. M., Svystak, V. V. (2018). Peculiarities of phytotherapy application in obesity. Ukraina. Zdorovia natsii, 2

31. Derymedvid, L. V., Bukhtiiarova, I. P. (2011). Mozhlyvosti zastosuvannia kombinatsii pryrodnykh antyoksydantiv za umov pervynnoi insulinorezystentnosti. Farmakolohiia ta likarska toksykolohiia, 2 (21), 37-42.

32. Novytska, A. V. (2016). Suchasni pidkhody do profilaktyky ta likuvannia patsiientiv z TsD 2-ho typu na rivni pervynnoi lanky nadannia medychnoi dopomohy, osoblyvosti medykamentoznoi terapii. Liky Ukrainy, 60-67.

33. Guzyk, M. M., Dyakun, K. O., Yanitska, L. V., Kuchmerovska, T. M. (2013). Influence of poly(ADP-ribose)polymerase inhibitors on some pa rameters of oxidative stress in blood leukocytes of rats with experimental diabetes. Украінський біохімічний журнал, 85 (1), 62-70.

34. Flavonoid kvertsetin - moschnoe oruzhie protiv kompleksa bolezney tsivilizatsii (2013). Prirodnaya meditsina, 1 (13), 6 9. Available at: https://health-ua.com/article/9396-flavonoid-kvertcetin-moshnoe-oruzhie-protiv-kompleksa-boleznej-tcivilizatc

35. Rogovsky, V. S., Matyushin, A. I., Shimanovsky, N. L. (2014). The prospects of quercetinum and its derivatives administration for prevention and treatment of atherosclerosis. Prirodnaya meditsina, 2 (14), 66-69.

36. Voloshyn, O. I., Hlubochenko, O. V., Pankiv, I. V., Holubchenko, V. H., Malkovych, N. M. (2019). Ooblyvosti fitoterapii tsukrovoho diabetu kriz pryzmu komor bidnosti y profilaktyy uskladnen (ohliad literatury). Mizhnarodnyi zhurnal endokrynolohii, 15 (3), 258-267.

Received date 11.05.2021

Accepted date 08.06.2021

Published date 30.06.2021

Viktoria Rybak*, Doctor of Biological Sciences, Associate Professor, Department of Normal and Pathological Physiology, National University of Pharmacy, Pushkinska str., 53, Kharkiv, Ukraine, 61002

Lyudmila Maloshtan, Doctor of Biological Sciences, Professor, Department of Biological Chemistry, National University of Pharmacy, Pushkinska str., 53, Kharkiv, Ukraine, 61002

Victoria Korol, PhD, Associate Professor, Department of Chemistry of Natural Compounds and Nutritiology, National University of Pharmacy, Pushkinska str., 53, Kharkiv, Ukraine, 61002

*Corresponding author: Viktoria Rybak, e-mail: viktoriarybak2@gmail.com 